\title{
THE PRINCIPLE OF SEPARATION OF POWERS IN POLITICAL SCIENCE
}

\begin{abstract}
The twentieth century doctrine considers separation of powers as a mechanism of constitutional technique that must be present in Political Science. In order to achieve this particular sense of separation of powers, this doctrine is based on the principles of specialization and independence. Separation of powers, therefore, refers to the division of government responsibilities into distinct branches to limit any one branch from exercising the core functions of another. The intent is to prevent the concentration of power and provide for checks and balances and establishment of democratic society.
\end{abstract}

Keywords: separation of powers, legislative body, political institution, structural development, functions of power.

The principle of separation of powers has been being defined for many centuries.

The origins of the principle of the separation of powers can be traced back as far as Ancient Greece. This principle was popularized much later by French philosopher Charles de Montesquieu in 1748 in his work L'Esprit des Lois (Spirit of the Laws) and by John Locke's ideas on collaboration of powers with legislative supremacy.

The corresponding article in Encyclopedia Britannica in 2007 concludes the contemporary view of the principle of separation of the legislative, executive and judicial powers. In the $20^{\text {th }}$ century, and, especially, since World War II, governmental involvement in numerous aspects of social and economic life has resulted in an enlargement of the scope of executive power. Some who fear the consequences of this for individual liberty have favored establishing means of appeal against executive and administrative decisions (for example, through an ombudsman), rather than attempting to reassert the doctrine of separation of powers.

Certain government systems prefer several principles, introducing certain exceptions to the separation of powers - since absolute separation is not only inexistent but would also be useless - in which the 'unchosen' principle shall be sacrificed, although not necessarily. These different interpretations of separation of powers, which will be explored thereafter, are generally identified as the European and American interpretations. (Lafitskii 1994; ed. by Strashun 1996)

The main goal of this article is the complex approach of separation of powers. This principle should be investigated in three aspects necessary for state management: structural, addressable and functional. The exclusive role in the process of formatting the principle of separation of powers is attributed to the legislative power which, generally, is implemented by such a body, whose members are representatives of people. A parliament holds a special place and in the constitutional system of any state it plays an exclusive role which, together with government form and state regime peculiarities (presidential or parliamentary republic) of the given country, can be different. A parliament is a nationwide representative 
body, the main function of which is the exercise of legislative power in the system of separation of powers. (ed. by Strashun 1996: 405; Avak'yan 1991)

The term "separation of powers" is defined as division of the legislative, executive and judicial functions of government among separate and independent bodies. Such separation has been argued as it delimits the possibility of arbitrary excesses by government, since the sanction of all three branches is required for making, executing, and administering of laws. (Encyclopedia Britannica 2007)

The origins of the principle of the separation of powers can be traced back as far as ancient Greece. It was made popular much later by French philosopher Charles de Montesquieu in 1748 in his work L'Esprit des Lois (Spirit of the Laws). He wrote that a nation's freedom depended on the three powers of governance-legislative, executive and judicial-each having their own separate institution. This principle has been widely used in the development of many democracies since that time.

According to Montesquieu's ideology the state is like a human body: the human heart is the Legislative Body, the brains - the Executive Body and the blood vessels - the Judicial Power. They should act mutually agreed, otherwise the state - the organism can't act properly and naturally and it will lead to willfulness of various characters. According to the provisions of the work "Spirit of the Laws» by Montesquieu in 1748, there can be no freedom as long as the legislative, executive and judicial powers are not separated and the judge endowed with legislative powers could turn into a tyrant, and the legislative power - into an "oppressor". (Montesk'e 1995: 215)

Montesquieu's argument that liberty is most effectively safeguarded by the separation of powers was inspired by the English constitution, although his interpretation of English political realities has since been disputed. Under his model, the political authority of the state is divided into legislative, executive and judicial powers. He asserted that, to most effectively promote liberty, these three powers must be separate and acting independently. Montesquieu's work was widely influential, most notably in America, where it profoundly influenced the framing of the Constitution. The US Constitution further precluded the concentration of political power by providing staggered terms in the key governmental bodies.

A historical analysis about the conception of the separation of powers was presented by M. Troper who points out some differences of understanding of legislative branch back in the eighteenth century from the one that we have nowadays. There the preeminent power was conceived as a subordinate task. This can be clearly seen in Montesquieu's description of the control tasks amongst powers, in which they are not portrayed as equally important, due to the preeminence of the first and the limited nature of the latter. (Troper 1990: 71-85)

What can be found in Montesquieu's work is the separation of powers as a negative rule that is consistent with the dominant theory of the time, the theory of state functions (Troper 1990: 79). This negative rule means that trusting all government functions to a single body must be avoided. According to the nature of the state power system this idea has its origins in the terms of "flexible" and "rigid" separation of powers which is exercised in the constitutional practice. (Montesk'e 1995)

The «flexible» separation is based on John Locke's ideas on collaboration of powers with legislative supremacy, while the "rigid" method starts with John Locke's observations on power balance and more correct separation of powers. The European constitutional and political practices make use of both of these models, whereas the classical example of the second model can be seen in the USA. Each model functions in particular conditions depending on many factors: political culture of society, the level of 
fulfillment of political institutions, legal traditions and mentality, psychology, legal awareness, level and development tendency of various branches of power, the dialectics of their functional and structural development etc.

Thus, if we assume what contemporary authors understand as separation of powers, to use the same name for Montesquieu's proposal would not be the best of ideas, just as Eisenmann argued. (Eisenmann 1933: 165-192) A question about functional or material separation which shall be discussed next is not just a disposition that avoids either the confusion of the different authorities' tasks or the fact that one authority holds an entire function. The idea is to achieve that 'power limits power'. Nevertheless, this theoretical negative rule must be complemented in such a way that it can be put in practice. We shall see in the following subsections that, in order to achieve this, scholars during the eighteenth century devised two key principles: specialization and independence. These principles break down into the two following senses of the notion 'separation of powers' in Michel Troper's theory.

The twentieth century doctrine considers separation of powers as a mechanism of constitutional technique that must be present, amongst others, in the design of a constitutional system in order to successfully limit power. In order to achieve this particular sense of separation of powers, this doctrine is based on the principles of specialization and independence. (Troper 1990; Vile 1967) Specialization means that the three classic functions of government - legislative, executive, and judicial - are distributed amongst different bodies, and must be carried out exclusively and entirely - without another body's influence- and it consequently must not interfere, prevent or render ineffective the exercise of functions of the others. Independence, on the other hand, refers to the relationships between said bodies, which must have enough freedom to act and eventually restrain each other from interfering with their functions. Independence manifests in the design of the various institutions that embody these powers, specially their constitution or appointment - the latter most not be made by another body-, their operation, and tenure of office -i.e., that their eventual revocation lays in pre-established legal causes instead of discretionary acts of other bodies. Nevertheless, independence can also be found as a prohibition of physical contact amongst bodies, the establishment of financial independence, and even rules on military safety. We must highlight that this doctrine has faced throughout the years strong objections (Troper 1990) that have had to be dealt with, not only from a theoretical perspective, but also through a practical approach. Firstly, the contradiction with the indivisibility of sovereignty was noted where the sovereign does not manifest but in the adoption or revision of the Constitution, and under the Constitution's rule no one is sovereign; all bodies are essentially limited. The second objection refers to an imminent state paralysis because of the opposition of powers. This eminently practical concern has existed for a long time, and has fostered a significant institutional evolution that has aimed to improve and give efficiency to the government functions. The third objection highlights the false perception of equivalent functions i.e., that these are not hierarchized - and the consequent impossible prospect of a real inter-organic control.

So, the modern constitutional systems show a great variety of arrangements of the legislative, executive and judicial processes, and the doctrine has consequently lost much of its rigidity and dogmatic purity. In the 20th century, and especially since World War II, governmental involvement in numerous aspects of social and economic life has resulted in an enlargement of the scope of executive power. Some who fear the consequences of this for individual liberty have favored establishing means of appeal against 
executive and administrative decisions (for example, through an ombudsman), rather than attempting to reassert the doctrine of the separation of powers. (Encyclopedia Britannica 2007)

Separation of powers, therefore, refers to the division of government responsibilities into distinct branches to limit any one branch from exercising the core functions of another. The intent is to prevent the concentration of power and provide for checks and balances.

As a guarantor of freedom and independence the separation of powers implies three separate functions: legislative, executive and judicial (justice).

The legislative body is represented by different names in different countries. The word "parliament" is a general term. In Great Britain, Italy and Japan it is called "Parliament". In the United States of America it's called Congress, in the Russian Federation - Federal Assembly, in Poland and Latvia - Sejm, in Germany - Bundestag, in France and Armenia - National Assembly ${ }^{1}$ (Xropanyowk 1997).

The executive body has different names in different countries too: in Armenia, Russia, France, Columbia, Czechoslovakia it's called "Government", in Germany - "Federal Government", in Japan "Cabinet", in Italy and Poland - "Council of Ministers", in China - "State Council", in Switzerland - "Federal Council". The name of the government may depend on the fact, whether the government session is chaired by or who participates in it. For example, in France or Belgium, if the government session is chaired by the President, then it's called Council of Ministers and if it's chaired by the Prime Minister - Cabinet. In Great Britain, for example (whose government staff - the Cabinet consists of 100 members, but never a single session was convened with this staff) the basic problems of the government are solved by the Cabinet. The latter consists of the Prime Minister and about 20 of the most influential ministers. Within the framework of its jurisdiction the Government adopts and publicizes decisions. Departmental units in the state are different, but they are all designed to preserve public order, to ensure the country's security, to create favorable conditions for the management of various spheres of public life. (Starodubovski, Chirkin 1986)

The executive authority bodies and public officials are not entitled to publish such mandatory acts that are not intended by law or are contrary to it. The executive power is of legal nature only if it presents a sub power. The executive power is accountable and responsible to the legislative power. In a legal state every citizen can appeal the illegal decisions and actions of executive bodies and officials. It should be noted that the role and the significance of government in the system of state bodies is largely perceived due to the form of government, the state mode features of the given country.

The availability of a legal state implies organization and existence of a strong and an independent legal authority. The judicial power is to ensure the implementation of laws, to protect the state law from violations related to the life activity of individuals and public spheres. As we know, the judicial power system implements jurisdiction based on the Constitution and laws. The application of coercive rules set by the Legislature is allowed or dictated by courts, while the executive body, not having legislative or judicial functions, functions based on the laws and in compliance with the implementation of laws and court decisions.

\footnotetext{
${ }^{1}$ HH orenq "Azgayin jhoghovi kanonakarg» (The RA Law on "the National Assembly Regulations") (20.02.2002.). www.parliament.am
} 
In modern countries the Court ensures the constitutional order, the legitimate rights and interests of citizens and organizations. The Court carries out a special control over the acts adopted by the other two bodies of the authority. (Vile 1967)

This quasi-exclusive nature of the independence and specialization principles will become evident when certain government systems prefer one of these principles, introducing certain exceptions to the separation of powers - since absolute separation not only is inexistent, but would also be useless - in which the 'unchosen' principle shall be sacrificed, although not necessarily. These different interpretations of the separation of powers, which will be explored in the following sections, are generally identified as the European and American interpretations. (Lafitskii 1994; ed. by Strashun 1996)

Referred to as the European interpretation, functional separation is a system in which authorities are specialized, yet not independent. In this case 'separation of powers' can be referred to as 'separation of functions'. It consists on a distribution of powers in which an authority has a single function and has no decisive participation in the exercise of the other. This is the case of parliamentary systems; in which independence is set aside since there is a fused executive/legislative authority manifested in a cabinet, yet is specialized, although there are exceptions. What stands out is that the organic interdependence allows collaboration from its own sector. This cooperation is the reason this interpretation is called "flexible" by those who encourage it. It refers to a necessary independence of powers, without them being necessarily specialized (Shokhin 1997). This is the case of presidential regimes, which is why this is also called the American interpretation. As mentioned above, the accent lays on its designation and duration, and exceptions are introduced mainly for specialization needs. Two clear examples of these two features are that in presidential regimes a rigorous independence would mean the absence of control mechanisms of parliamentary systems such as dissolution of parliament or political accountability, and, on the other hand, authorities do not necessarily confine themselves to their sheer functions, an example being the participation of the President in the legislative process besides its executive functions. At this point, and because we have already analyzed functional separation, important questions arise. Should we say that we are before a rigid separation because of a rigorous independence? Or is it a flexible separation because of the lack of a strict specialization? Should we highlight the foreseen result of the exceptions and therefore speak of 'checks and balances'? And, according to this last hypothesis: should we say that the 'checks and balances' system is a synonym of a 'rigid' or of a 'flexible' separation of powers? Now let's analyze of a term balance of powers that is no related to the specialization/independence dichotomy, but can be seen as a step forward in the theory of separation of powers, and is also one step closer to power control. This organizational constitutional technique, considered a synonym of 'division of powers' or 'checks and balances', intends to achieve a state of balance between the authorities, once they have been separated - the way this is achieved varies from system to system. Seen like this, the separation of powers is incompatible with the specialization principle, since the bodies do not execute their functions as a whole in an exclusive manner; it therefore fosters collaboration and the necessary functions to oppose to each other, conditioning or preventing its exercise, so that "power restrains power". The goal is to avoid that different government authorities exceed their given functions. As a consequence, in order to avoid despotism, political power is first distributed, trusted to a variety of bodies - which means that, since concurrence is necessary, the action of one may eventually be stopped by the action of another- and subsequently control and influence powers are given to these bodies. At first, since a balance between 
the legislative and executive branch was not conceivable because they were not considered as equivalent functions, the only way to achieve this balance was inside the legislative branch, by its division into two chambers that historically represented different social strata - such was the case of the House of Commons and the House of Lords in United Kingdom - but that today represent different interests - e.g., the representation of the members of a federation on one hand and the representation of the people on the other. In order to complement this control, each chamber has both a partial legislative function and a distinct function. Over time the functions and importance of the executive branch increased, which is why it was eventually given recognition and control functions through several techniques, such as veto during the legislative process, introduced by presidential systems. Another significant contribution of the first presidential system was the set of mechanisms established in order to avoid a potential paralysis without sacrificing autonomy. (Chirkin 1999) To achieve this, the constitutional validity of certain government activities -also known as 'contact points' or 'strategic points of the political process' - was conditioned to a mandatory cooperation between powers, creating a coordination interdependence, essentially different from the integration interdependence of parliamentary systems. The general acceptance of this technique made cooperation a key instrument to distribute and balance powers. This seems ironic, since the last section described this sense of 'separation of powers' as 'a step forward in the theory of separation of powers'. We must therefore point out that even though concepts such as 'checks' and 'balances' are already present in the literature from far back, we do not refer to a chronological evolution, but a conceptual one. The existence of articles in which one would already find concepts as balance or cooperation did not stop the conception of the separation of powers of specialization and independence from being developed - a conception that, even though this paper has tried to prove that is not perhaps the best approach to study the different systems of government, is the most widely used in our time, until recently. On one hand we have horizontal controls that operate within the government and move from side to side on the same level. (Chirkin 2001) According to the author, these ought to be complemented by and confronted with vertical controls, which involve an interaction - or confrontation - between the power holders that have been constitutionally established and are in charge of conducting government process - parliament, government, courts, and the electorate - society, which can manifest itself in three different ways, constituting three techniques or scopes for this kind of control: federalism, human rights, (and its guarantee mechanisms), and pluralism ${ }^{2}$. Federalism was not considered a control technique until the late eighteen century. The very first federal unions of state governments were based at first on vassal or feudal relationships, which meant the preponderance of some of the members of the association. It was until the federal government created by the American Constitution that we observe a true vertical control, in which there is a confrontation between two separate territorial sovereignties two different sets of government institutions - and a distribution of functions established in the Constitution. This distribution of functions allows the achievement of national and regional goals by giving both the central and regional governments the necessary autonomy to work independently but at the same time ensuring a mutual balance that allows the control of power when needed. Even though one may think of federalism as a different constitutional technique than that of separation of powers, its belonging to these different meanings of the concept has sense, as mentioned above, since it applies the

\footnotetext{
${ }^{2}$ HH Ankaxowt'yan Hr'chakagir (RA Declaration of Independence) (23.08.1990). www.parliament.am
} 
principle of distribution of powers and is therefore incompatible with an autocratic regime characterized by a concentration of political power, either it is in a single person, an assembly, committee, board or party. (Kozlova 1999) From this analysis of the six senses of 'separation of powers' we can note some sort of continuity between the concepts, whose basis is search for deconcentrating of power. However, we can also observe important differences, nuances in the interpretation and application of what began as a mere negative rule that have had an important effect on government design, a matter that is still subject of debate in the ongoing process of democratization of governments. No federate state can function without a written Constitution. This is specifically the case of functional and material separations of powers, a widely spread theory that has been used to identify different systems of government: functional separation as a feature of parliamentary systems, and material separation as characteristic of presidential systems. The debate has focused on determining which the best system; the best way to interpret and apply this kind of 'separation of powers', and therefore which elements can be considered as essential and which can be sacrificed in order to successfully implement this constitutional technique without it losing its essence. The main problem of this kind of approach is that scholars tend to generalize and stereotype when speaking of rigidity or flexibility of the separation of powers in either presidential or parliamentary regimes, when the truth is that it this is a comparison that doesn't have much sense, since we can speak of rigidity or flexibility in either system, because both have introduced exceptions. To this we must add that there is a theoretical consensus in this particular aspect, and it is difficult to find a single scholar that advocates for a rigid separation. In this sense, it would seem that the interpretation of the separation of powers in which there is a search for balancing all government powers - which means a necessary cooperation between them - is a step forward in perfecting a separation of powers that allows an effective control of power, especially because the methods used to achieve this balance vary from system to system and therefore may easily respond to specific contextual needs. This brings us to another observation that should also be taken into consideration: we must distinguish between the separation of powers as a theoretical product - in which we can speak of paradigms, dissect, classify, compare, etc. - and as a historical product, as a consequence of the evolution of institutions as a response to the changes of the political, social, and economical environment. (Shokhin 1997)

The separation of powers should be in three aspects: structural, addressable and functional. The structural approach of separation of powers implies the activities of each of the branches of power through separate levels and bodies of state apparatus, which are relatively independent from each other. Its purpose is not to concentrate the powers in the hands of one body, which can lead to state power abuse. Each branch of power should deal only with the functions entrusted to it, and only in some cases they can be granted certain control rights, for example, state budget execution control of powers by the National Assembly. Any form of connection of the judicial power to the legislative or executive power, is simply, unacceptable. (Hakobyan 2007)

The addressable aspect of the separation of powers also plays an important role in the realization of the principle of separation of powers. To ensure this principle, parliamentary members can't be engaged in entrepreneurial activities, hold positions in public or self-governing bodies or non-profit organizations, perform other paid job except for scientific, educational and creative work. This restriction also applies to 
government officials, judges and members of the Constitutional Court ${ }^{3}$. (Harowtyownyan, Vagharshyan 2010)

The incompatibility of parliamentary mandate with other positions is inherent in the absolute majority of states. Although it should be noted that not in all states parliamentary members are banned to hold any other position simultaneously. Parliamentary members in countries with features typical for a parliamentary republic and a parliamentary monarchy may also be simultaneously government members, with the exception of the Netherlands, Norway and Sweden. For example, in Great Britain a parliament member may also be a government member.

A parliament is not only a law-making body, but a representative one as well. With RF Constitution "The Federal Assembly...is the representative and legislative body of the Russian Federation". This means that it acts as a body expressing the will and interests of the people (nation). In addition to the law-making activities, the grounds for the decision of domestic and foreign policy, the development and adoption of fundamental projects and budget approval etc. are within its jurisdiction. (Grankin 1999)

In order to be able to fulfill their entire social functions, a number of authorities are assigned to parliaments, which, together with these functions, make up their constitutional status.

In a state the powers in terms of a parliamentary role are both limited and unlimited.

States, having parliaments with unrestricted powers, as a rule, do not set an exhaustive list of parliamentary powers.

Japan's Constitution, for instance, does not contain any provision that might exhaustively define Parliament's authorities. The same we can say about China or the former USSR. Great Britain is a striking example of the said.

In Armenian reality, the national or secular assemblies were held even in ancient times. National assemblies, of course, not by modern perception, were held in Armenia from time to time, when the nation had to make fateful and serious decisions on the issues they were facing at that time, as well as to adopt social relations regulating rules. The Armenian Church, due to circumstances, was obliged to become the head of the ministerial power and legislation. This is, of course, very far from the essential parliament institute, which implies permanently functioning representative legislative body elected by people, but it contains its original elements: the alderman, discussed and debated issues, adopted by voting rules and decisive decisions and accordingly organized its activities and established relations. (Xachatryan 1994)

Thus, speaking of the peculiarities of the legislative power, almost in all countries the supreme lawmaking function is implemented by such a body, whose members are representatives of people (society) ${ }^{4}$. A parliament holds a special place and in the constitutional system of any state plays an exclusive role, which with government form and state regime peculiarities (presidential or parliamentary republic) of the given country can be different. A parliament is a nationwide representative body, the main function of

\footnotetext{
${ }^{3}$ HH Sahmanadrowt'yown. Hodvac'ner 65, 45, 88, 98 (y'ndownvac' 05.07.1995, p'op'oxvac' 27.11.2005) (RA Constitution. Articles 65, 45, 88, 98 (adopted on 05.07.1995, amended and supplemented on 27.11.2005)). www.parliament.am

${ }^{4}$ HH Y'ntrakan Orensgirq (RA Election Code) (26.05.2011). www.parliament.am
} 
which is the exercise of the legislative power in the system of separation of powers (ed. by Strashun 1996: 405; Avak'yan 1991).

\section{REFERENCES}

Avak'yan S.A., (1991). Deputat: status i deyatel'nost' (A Parliament Member: Status and Activities). Moskva: izdatel'stvo Politicheskaya literatura.

Chirkin V.E. (1999). Konstitutsionnyi zakon zarubezhnykh stran (The Constitutional Law of Foreign Countries). Moskva: izdatel'stvo Yurist.

Chirkin V.E. (2001). Konstitutsionnyi zakon zarubezhnykh stran (The Constitutional Law of Foreign Countries). Moskva: izdatel'stvo Yurist.

Eisenmann, Ch. (1933). L'Esprit des lois et la séparation des pouvoirs. In Mélanges Carré de Malberg. Sirey.

Grankin I.V. (1999). Parlament v Rossii (The Parliament in Russia). Moskva: izdatel'stvo AO Konsaltbankir. Hakobyan H.H. (2007). Par'lamenty' \& par'lamentarizmy' Hayastani Hanrapetowt'yownowm (The Parliament and Parliamentarism in the Republic of Armenia). Er\&an.

Harowt'yownyan G., Vagharshyan A. (2010). Hayastani Hanrapetowt'yan Sahmanadrowt'yan meknabanowt'yownner (Commentaries on the RA Constitution). Er\&an Iravownq.

Hoiberg, D. (Ed.) (2007). Encyclopedia Britannica. (15 $5^{\text {th }}$ edition).

Kozlova E.I. (1999). Konstitucionnyi zakon Rossii (The Constitutional Law of Russia). Moskva.

Lafitskii V.I. (1994). Kongress SAHA. Parlamenty mira (The US Congress, The Parliaments of the World). Moskva: Progress.

Montesk'e Sh. (1995). Izbrannye trudy (Selected Works). Moskva.

Shokhin A.N. (1997). Vzaimodeistvie vlastei v zakonodatel'nom protsesse (Cooperation of the Authorities in the Legislative Process). Moskva: izdatel'stvo Nash dom.

Starodubovskii B.A., Chirkin V.E. (1986). Gosudarstvennoe pravo burzhuaznykh stran I stran, osvobodivshikhsya ot kolonial'noi zavisimosti (State Law of Bourgeois and Liberated Countries). Moskva.

Strashun B.A. (red.) (1996). Konstitutsiya zarubezhnykh stran (The Constitution of Foreign Countries). Moskva.

Troper, M. (1990). Montesquieu e la separazione dei poteri negli Stati Uniti. In Materiali per una Storia della Cultura giuridica. (Anno XX, num. 1). Genova.

Vile, M. J. (1967). Constitutionalism and the Separation of Powers. Oxford: Clarendon Press.

Xachatryan H. (1994). Par'lament \& patgamavor (Parliament and Member of Parliament). Er\&an Areg.

Xropanyowk V.N.(1997). Petowt'yan \& iravownqi tesowt'yown (Theory of State and Law). Er\&an. 